\title{
Summertime dosage-dependent hypersensitivity to an angiotensin II receptor blocker
}

\author{
Donald R Forsdyke*
}

\begin{abstract}
Background: Summertime dips in blood pressure (BP), both in normotensive and hypertensive subjects, are well known. However, the dips are small and are not related to particular forms or doses of antihypertensive medication. Nevertheless it is the practice in some quarters to decrease antihypertensive medication in summer, and/or to increase in winter. Large scale studies being inconclusive, there are calls for long-term examination of the relationship between environmental temperature and blood pressure in single individuals under medication.

Case presentation: While analyzing data from a subject whose BP had been controlled for a decade with the angiotensin-II receptor blocker losartan, an extreme, dosage-dependent, summertime dip came to light. Downward dosage adjustment appeared essential and may have prevented hypotension-related pathology.

Conclusion: The benefits of aggressive medication (the "J curve" phenomenon) being debated, the possibility of seasonal hypersensitivity, perhaps explicable in terms of differential signaling by countervailing receptors, should be taken into account when considering dosage adjustments in hypertensive subjects.
\end{abstract}

Keywords: Environmental temperature, Angiotensin II receptor, Losartan, Hypotension, Acute kidney injury, J-curve

\section{Background}

\section{Conflicting opinions on seasonal dosage adjustment}

Small summertime declines in blood pressure (e.g. 5-10 $\mathrm{mm} \mathrm{Hg}$ ) have long been known, both in normotensive and hypertensive subjects. Indeed, adverse cardiovascular events being more frequent in winter, it is the practice in some quarters to decrease antihypertensive medication in summer, and/or increase in winter [1]. But this is controversial. Ambulatory blood pressure (ABP) recordings often reveal a small dip in BP values when subjects are resting at night [2]. In Italy, Modesti et al. reported in 2006 [3] that in summer this night-time dipping was less evident, and systolic values (SBPs) were slightly increased; it was only with day-time BP measurements that a summer decrease was evident. They cautioned against reducing dosage of antihypertensive medication in hot weather. On the other hand, based on

*Correspondence: forsdyke@queensu.ca

Department of Biomedical and Molecular Sciences, Queen's University, Kingston, ON K7L3N6, Canada clinic BP measurements of 500,000 subjects drawn from ten climatically diverse regions of China, in 2012 Lewington et al. [4] affirmed that "higher doses or additional $\operatorname{drug}(\mathrm{s})$ may be required in winter to achieve the same blood pressure control as at other times of the year". In other words, they advised lowering dosage in summertime. Indeed, in 2013 Modesti came to agree that "it is possible that heat-exposed subjects need lower dosages... because of lower BP in warm conditions" [5].

However, seasonal influences on responses to specific antihypertensive medications are not well documented. Apart from logistic considerations (e.g. patient confidentiality), this may be due the relative newness of some medications, so that long-term studies are not yet available. In Japan, Hozawa et al. [6] relied on the home BP measurements of volunteers, but had no information on medications. In Scotland, Aubinière-Robb et al. [7] relied on clinic measurements of treated hypertensive subjects, but had "incomplete prescribing data". Furthermore, their location implied more concern for potential adverse effects of increases in BP in cold weather, than of 
decreases in BP in hot weather. The subtropical island of Taiwan has temperatures closer to those in summer-time Ontario, but the winter-summer variation is much less. For Taiwan, Tu et al. [8] reported no influence of season on the response to antihypertensive medication, but type and dosage were unspecified.

The most definitive study to date is the above noted work of Lewington et al. [4]. The percentage differences between summer and winter did not differ between those on antihypertensive medication (type unspecified), and those who were not. However, absolute differences were greater in hypertensive subjects (differences averaging 11.0 versus $9.6 \mathrm{~mm} \mathrm{Hg}$ ). Floras has recently cautioned that when marginal hypertension is diagnosed in summer-time, initiating therapeutic dosages may be suboptimum, but the possibility of extreme seasonal variation in sensitivity to medication was not entertained [9].

\section{Calls for long-term single patient studies}

Despite many studies, seasonal variations in BP are not clearly related to particular forms or dosages of medication in individual subjects. It is recognized that "patients are exposed to antihypertensive treatment for decades; yet, long-term safety of these drugs is not well-reported. Most prospective randomised trials end after a few years without long-term follow up" [10]. Indeed, in 2013 Modesti et al. [11] declared that some of the limitations of their approach "would be addressed in future studies based on repeated measurements according to a longitudinal design and focusing on the assessment of temperature and BP changes within a single individual". This need for long-term single-individual studies was echoed in 2012 by Cuspidi et al. [12], and in 2013 by Tomlinson et al. [13], who called for "carefully designed studies using individual level patient data to examine this issue in more depth". To some extent, the present study meets this requirement, but regrettably with the absence of night readings. In 2011 Handler [14] reported a case where the subject, based on home BP readings and postural hypotension, had opted to stop medication in summer, but there were few details. In 2013 Chen et al. [15] reported a 3 year follow-up of hypertensives treated with the angiotensin converting enzyme (ACE) inhibitor (benazepril); average seasonal fluctuations were of the same order as reported by Lewington et al. [4]. It was concluded that "patients should monitor and treat blood pressure more carefully in cold days".

\section{J-curve phenomenon}

Seasonal BP variations are not seen as related to the socalled "J curve" phenomenon [16]. While the benefits of decreasing blood pressure are clear, there comes a point below which there are negative consequences, marked by a J-like inflection on plots of adverse cardiovascular events against BP. Such consequences include acute kidney injury, now becoming more evident among those on medication [13]. Indeed, it is held that its "important implications for clinical practice should make investigation on the J-curve phenomenon a priority for cardiovascular medicine" [16].

While analyzing data from a subject whose BP had been controlled for a decade with the angiotensin-II receptor blocker (ARB) losartan, an extreme, potentially dangerous, summer-time influence came to light [17]. ARBs being treatment of choice for millions of subjects, it is unlikely this is an isolated case.

\section{Case presentation}

\section{Materials and methods}

In August 1999, mild hypertension (circa 150/90 mm Hg) was found during routine examination of a 60 year old biomedical researcher. In the 1960s he had been briefly involved in hypertension research ${ }^{\mathrm{a}}$. When studying the activation of cultured human lymphocytes in the 1980s he discovered a gene (RGS-2) [18] that was later found to regulate BP $[19,20]$. With appreciation of possible immunological aspects of hypertension [21], he followed the course of his new condition with deep professional interest. This led to his carrying out all readings for, and authoring, the present report. Beginning in January 2000, resting $B P$ readings were taken at least once daily (usually both in early morning and late evening) by the subject at his home. The continuing accuracy of his Omron digital BP monitor (model HEM-712C) was ascertained by comparing with readings from his mercury sphygmomanometer, with those obtained in his physician's office ${ }^{\mathrm{b}}$ and, in 2015, by comparing with a new Omron monitor (HEM-7121C).

Since Ontario Climate Centre records of daily temperatures for the subject's lakeside city (Kingston, Ontario) did not become available until 2008, values for a location $24 \mathrm{~km}$ north (Hartington) were employed. The latter tends to be $2-3^{\circ}$ cooler/hotter in winter/summer than Kingston. In the period of this study, indoor temperatures were regulated at around $22^{\circ} \mathrm{C}$ during cold weather. In summer months fans were employed and only short periods were spent in air-conditioned environments.

Throughout the study period standard blood and urine tests remained within normal ranges, except that on occasions creatinine levels approached high normal. The subject's resting pulse had registered around 50/ min for many years. His lifestyle was that of an academic workaholic-several hours a day at a computer interrupted by frequent brisk walks, and twice weekly runs $(2 \mathrm{~km})$. Height and weight had remained relatively constant throughout adult life (currently $1.76 \mathrm{~m}$ and $72 \mathrm{~kg}$; 
BMI = 23.2). The hypertension was assumed to be primary ('essential'), and was not further investigated. However, at an early stage antihypertensive medication was associated with postural hypotension and an instance of acute renal colic. These encouraged close home BP monitoring with dosage adjustment by the subject targeting $130 / 80 \mathrm{~mm} \mathrm{Hg}$. While the present report is primarily concerned with a 12 year period when losartan was the sole medication (2003-2014), the stage will be set with a brief account of an initial 3 year exploratory period with various other medications.

\section{The period 2000-2002}

In the year 2000, two one-month trials (Feb., Apr.) of daily losartan $(25 \mathrm{mg})$ with chlorothiazide $(12.5 \mathrm{mg})$ resulted in progressive falls in day-time BP, with some systolic values (SBP) around $100 \mathrm{~mm} \mathrm{Hg}$ (Figure 1). Consistent with this, the subject experienced some dizziness on standing up abruptly. On cessation of these medications, BP values progressively returned to previous levels.

In June, chlorothiazide alone $(12.5 \mathrm{mg})$ had little effect. However, losartan alone $(25 \mathrm{mg})$, taken at the height of summer (August, with environmental temperatures approaching $30^{\circ} \mathrm{C}$ ), produced a progressive and more profound fall in pressure, with SBP values again below $100 \mathrm{~mm} \mathrm{Hg}$, and diastolic (DPB) values approaching $60 \mathrm{~mm} \mathrm{Hg}$. Shortly after cessation of therapy there was acute renal colic and blood pressure rose abruptly (Figure 1). A ureteral stone observed on X-rays was presumed to have passed in the urine.

In view of the timing, and the subject not having previously experienced renal colic, it was considered likely that stone formation had been facilitated by hypotension. Indeed, there is now increasing awareness that acute kidney injury (AKI) can follow ARB medication in a range of settings, particularly during acute hypovolemic illness [13]. Medications were avoided for the next 2 years and pressure values remained relatively constant in the 150/90 range. In the summer of 2001 there was the expected small BP dip, which correlated inversely with environmental temperature (Figure 2).

In the summer of 2002 mild hypertension was confirmed by one session of $24 \mathrm{~h}$ ambulatory BP (ABP) monitoring and, for a 6 week period (beginning in the

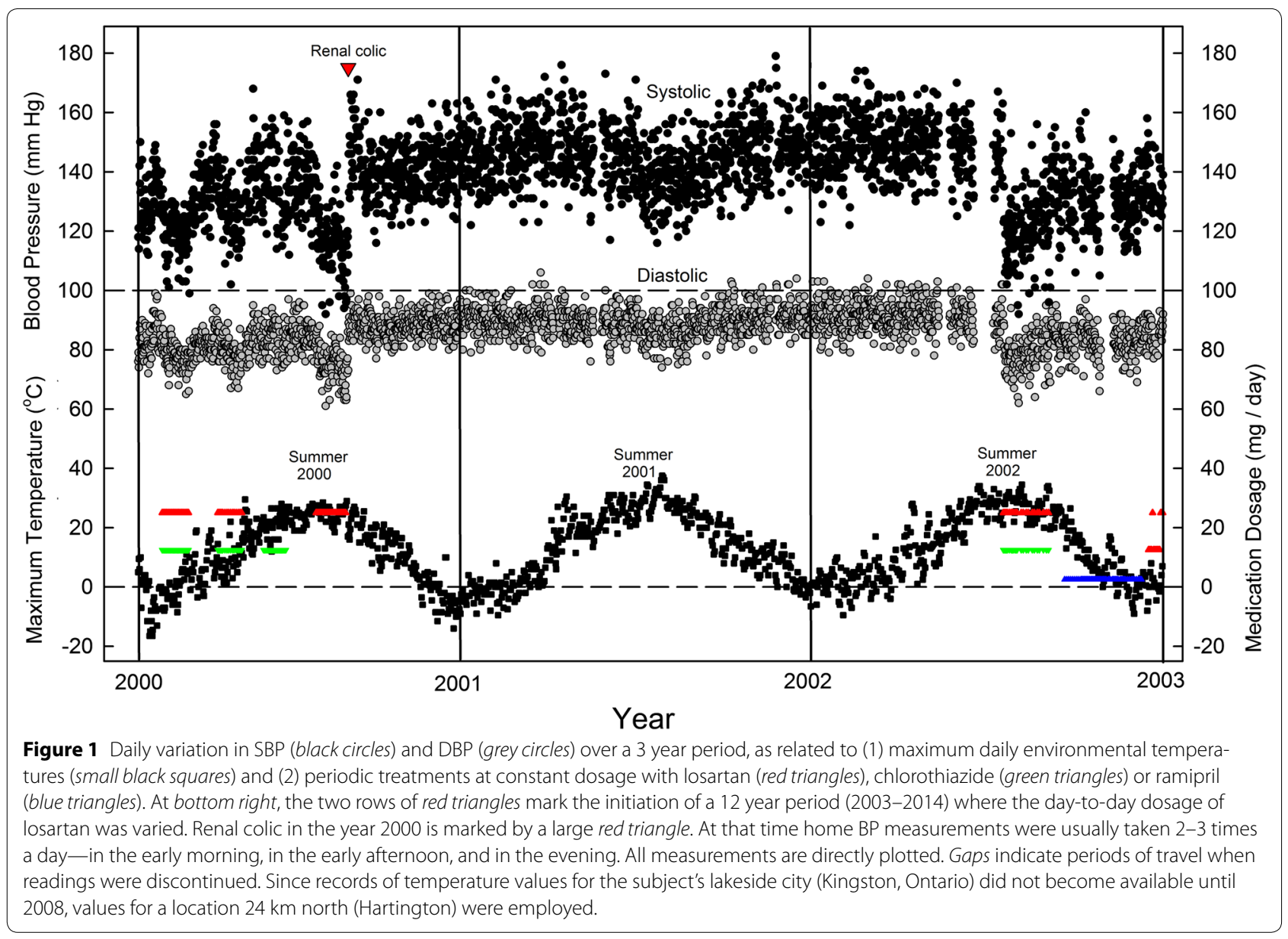




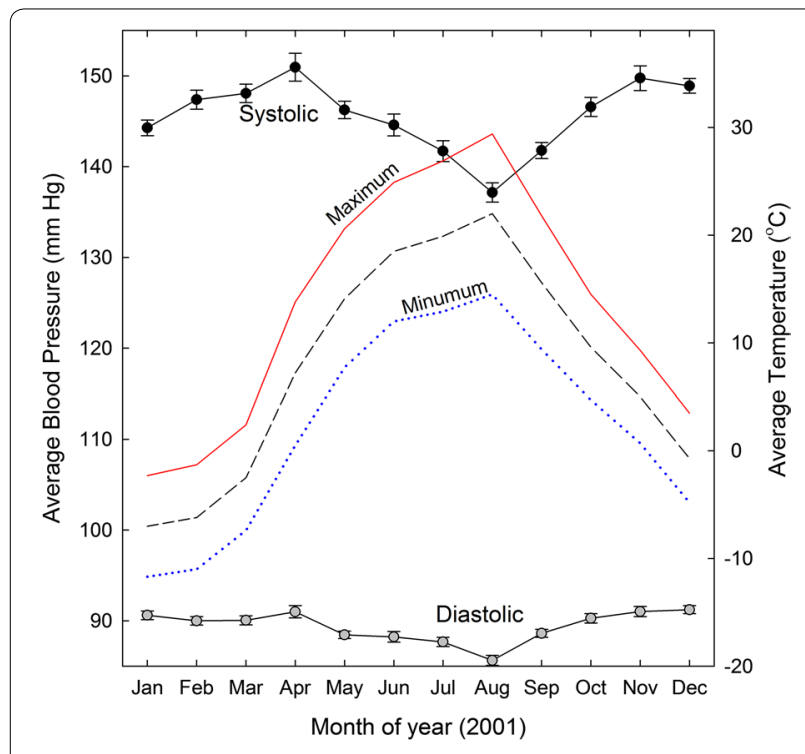

Figure 2 Seasonal variation in SBP and DBP in absence of hypertensive medication. Daily values for each month in the year 2001 are averaged and plotted with standard errors. Corresponding monthly average temperature values are shown without symbols (maximum, continuous red line; average, dashed black line; minimum, dotted blue line).

last week of July), daily combination therapy with losar$\tan (25 \mathrm{mg})$ and chlorothiazide (12.5 $\mathrm{mg}$ ) was resumed (Figure 1). Again, there were extreme declines in pressure values and some minor dizzy episodes. BP was controlled more satisfactorily with the ACE inhibitor, ramipril (2.5 mg/day; late September to early December). However the subject experienced a persistent dry cough, so ramipril was discontinued. Although there had been some dry coughing with losartan, therapy with losartan alone was resumed at the end of December 2002 (rows of red triangles at extreme right in Figure 1). Dosage was adjusted daily by the subject according to his BP readings. This proved satisfactory for the next 12 years, despite some dry coughing.

\section{The period 2003-2014}

With various combinations of half $(12.5 \mathrm{mg})$ and whole (25 mg) tablets, daily losartan dosage was varied over the range, $0,12.5,25,37.7$ and $50 \mathrm{mg}$, taken either in the early morning or, from December 2010 onwards, split between mornings and evenings (under guidance of BP readings taken at the same times). Further fine adjustment was attempted by trying to maintain regular dosage patterns-e.g. 12.5, 25, 12.5, $25 \mathrm{mg}$, etc. Apart from weekly sildenafil citrate $(50 \mathrm{mg})$, which tended to lower $\mathrm{BP}$, losartan was the sole medication.

For the first 4 years (2003-2006) the required average losartan dose was $16 \mathrm{mg} /$ day, rising to $18 \mathrm{mg} /$ day for the next 3 years (2007-2009). Thereafter, the average requirement rose from $19 \mathrm{mg} /$ day (2010) to $44 \mathrm{mg}$ / day (2013) and $33 \mathrm{mg} /$ day (2014). An example of the ability to fine-tune day-time BP readings over the 20032009 period is shown for the year 2007 (Figure 3). With relatively constant losartan dosages (average $18 \mathrm{mg} /$ day) blood pressure readings were maintained at acceptable values $(130 / 80 \mathrm{~mm} \mathrm{Hg})$. There was generally no need for special dosage adjustments in the hot summer season.

These same BP values were sustained in the 2010-2014 period. However, when, for some unknown reason, the total losartan requirement increased, an extreme downward dosage adjustment became necessary in the summer season. This is shown for the year 2012 in Figure 4.

The detailed BP plot for 2011, when increased losartan dosage first became necessary, is of special interest (Figure 5). BP levels were maintained relatively constant by decreasing losartan dosage in the summer months and increasing dosage in the following winter. The sub-zero maximum daily temperatures early in the year were associated with $25 \mathrm{mg} /$ day dosages. The increase in losartan requirement to $50 \mathrm{mg} /$ day began in the late fall when maximum temperatures were still above zero, so seeming to reflect an influence internal to the subject, as well as from the environment.

Monthly losartan requirements for the entire 12 year period are shown in Figure 6. At the doses employed between 2003 and 2009 (average 16-18 mg/day), usually no seasonal adjustment was needed. In 2006 (a particularly hot year), only minor adjustment was needed. The plot for 2011 was distinctive. At first the requirement was high, but decreased to previous values during spring and summer. However, later in the year as environmental temperature declined, there was a sharp increase in losartan requirement. Subsequently (2012-2014), a summer requirement for extreme downward dosage adjustment emerged.

\section{Relationship between temperature and BP}

Plots of $\mathrm{BP}$ and losartan dosage against temperature showed minimal influence of temperature during the 2003-2009 period. Figure 7 shows data for 2007 (from Figure 3). The regression line for losartan dosage (red) was essentially horizontal. However, plots for the year 2011 (Figure 8) showed a biphasic linear regression fit to losartan dosage. The ascending limb of the regression reflects the dosage increase from $25 \mathrm{mg} /$ day in the cold early part of the year, to $50 \mathrm{mg} /$ day in the less cold late part of the year. The descending limb of the regression reflects the decreasing requirement during the summer months.

Figure 9 shows regression plots for the entire 20032014 period. The curves were essentially horizontal for 


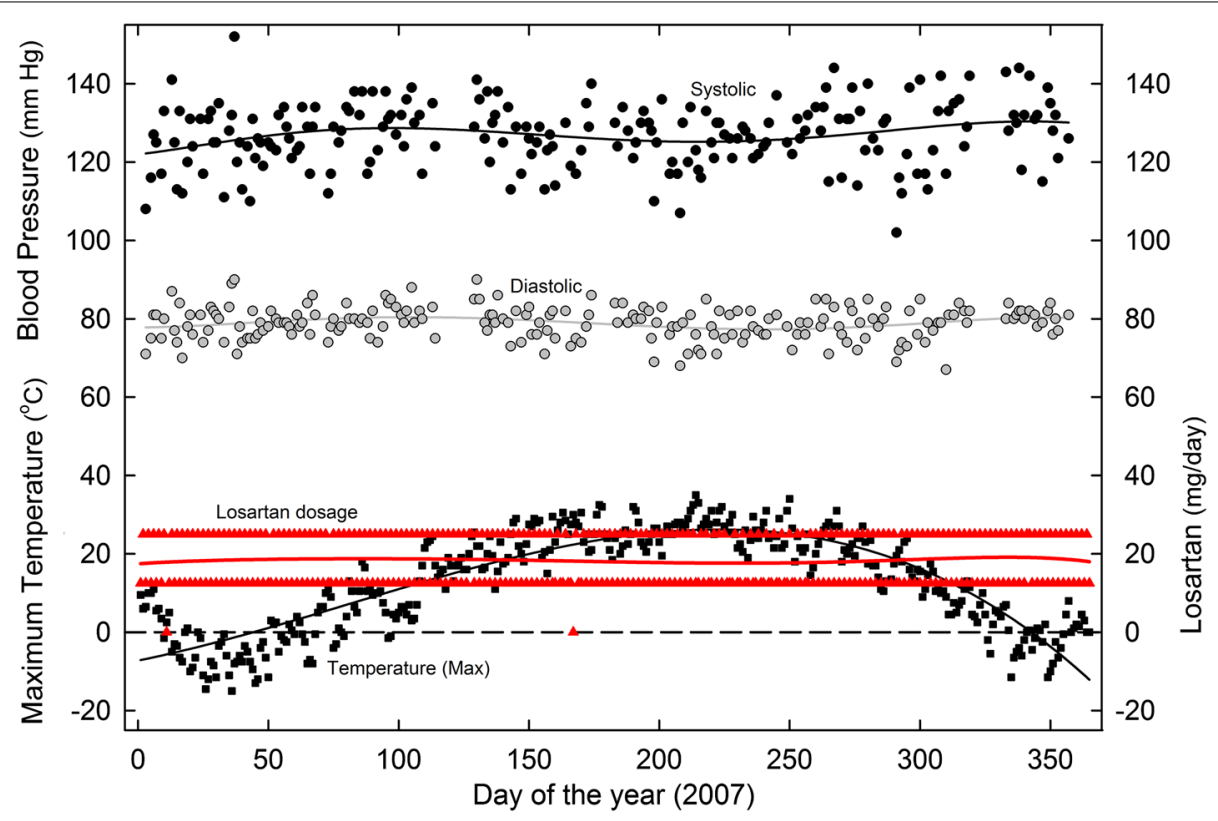

Figure 3 Daily variation in SBP and DBP in 2007, as related to (1) maximum daily environmental temperatures and (2) varying losartan dosage. Home BP measurements were usually twice daily - in the early morning and late evening — and these values were averaged for plotting. Leastsquares regression (sixth order) polynomial fits to the points are shown as continuous lines (the fit is third order for the black temperature line). For other details see Figure 1 .

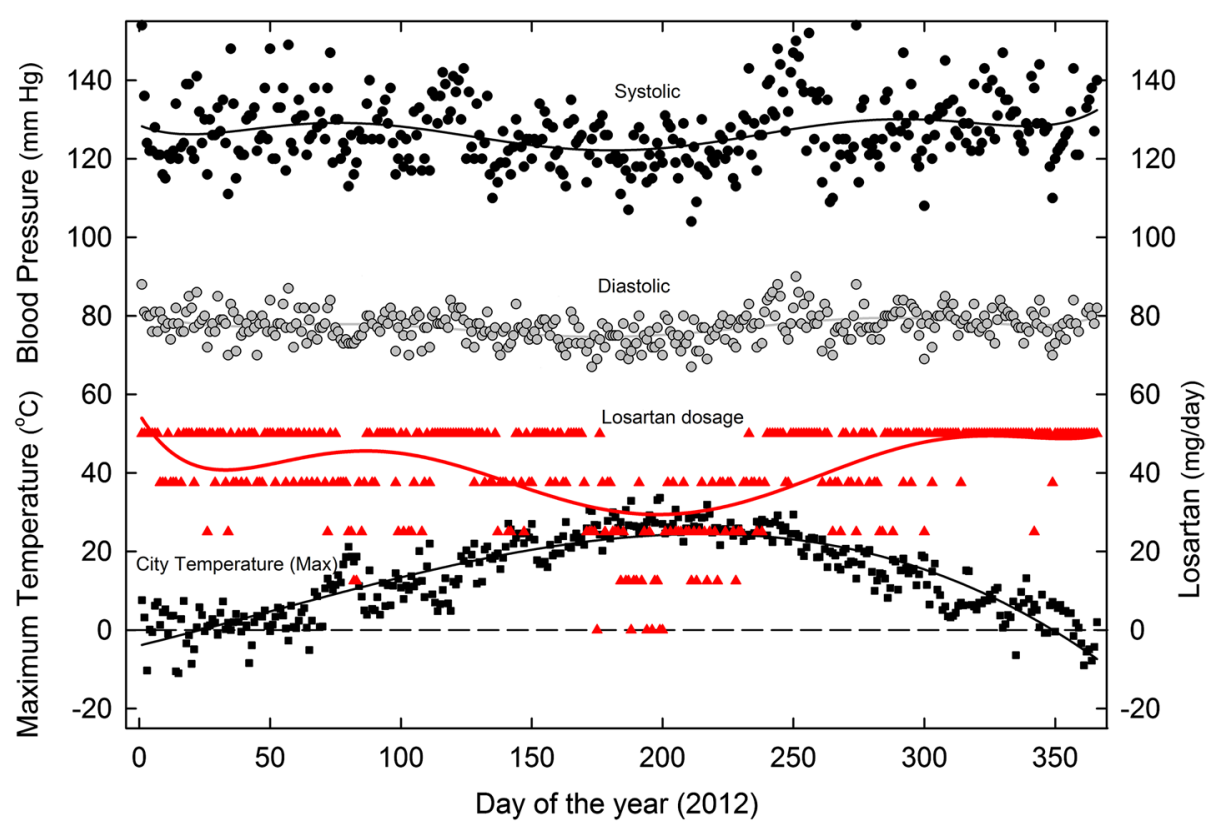

Figure 4 Daily variation in SBP and DBP in 2012, as related to (1) maximum daily environmental temperatures and (2) varying losartan dosage. For details see Figures $1,3$.

2003-2009. Thus, dosage was independent of temperature. In 2010 came the first indication of the extreme seasonal influence-explicit from 2012 onwards. Indeed, by extrapolation, under these conditions losartan could have been abandoned at around $34^{\circ} \mathrm{C}$.

\section{Discussion}

The present study arose from the belief that an interference with physiological homeostatic controls, which was deemed necessary for management of primary hypertension, would require close BP assessment-an assessment 


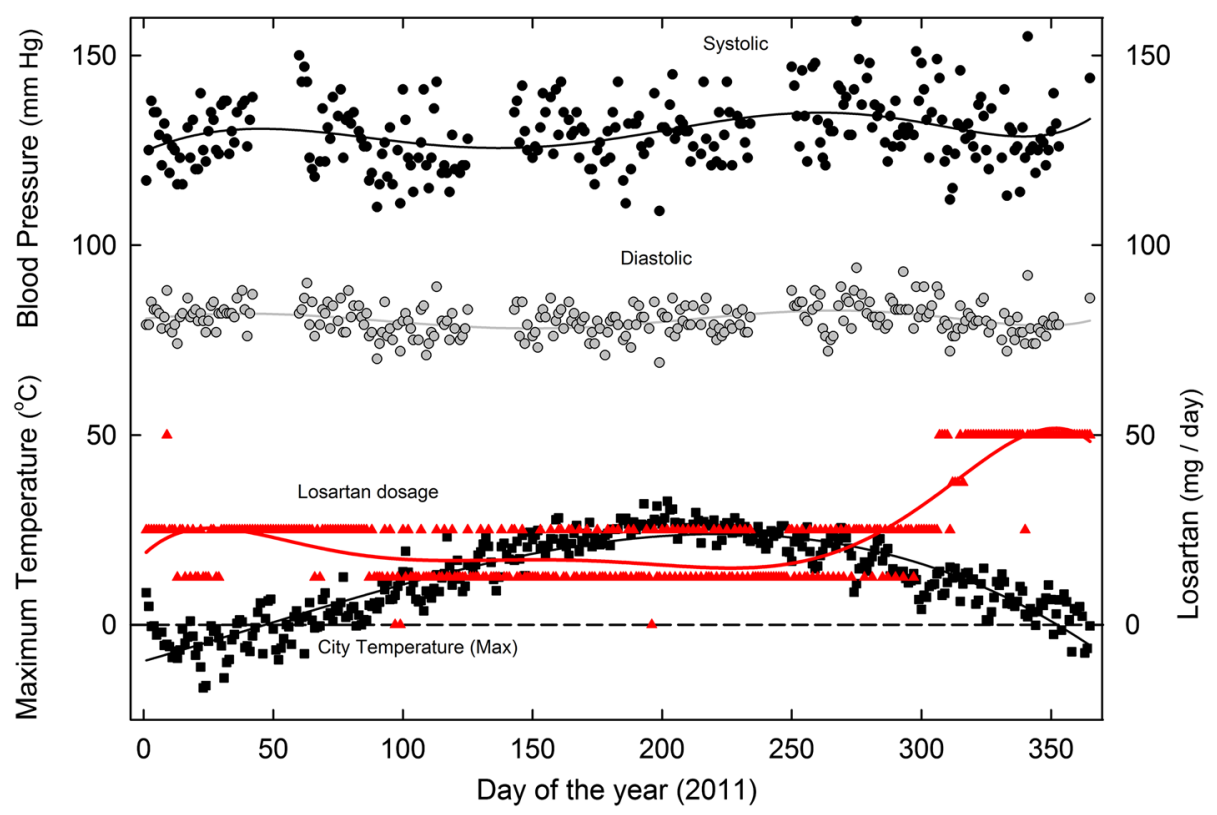

Figure 5 Daily variation in SBP and DBP in 2011, as related to (1) maximum daily environmental temperatures and (2) varying losartan dosage. For details see Figures $1,3$.

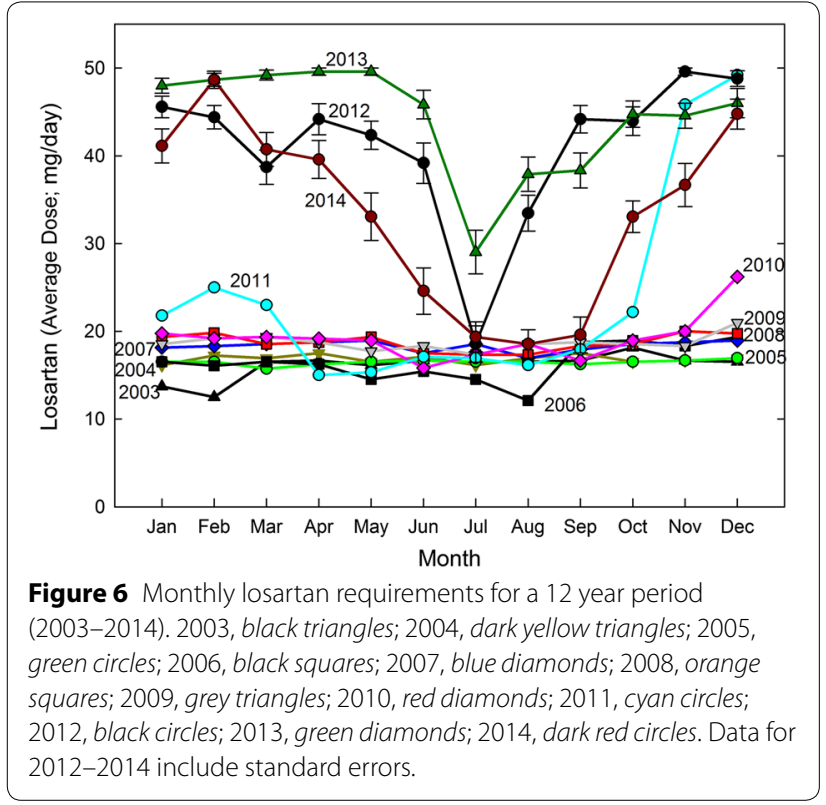

which would be facilitated by the digital devices that had become available for home-monitoring. Whether it is the actual BP level, or variation in that level, that is most responsible for adverse clinical consequences, is much debated $[9,22]$. Here, the day-to-day adjustment of losartan dosage to observed daily BP levels would seem to address both factors.

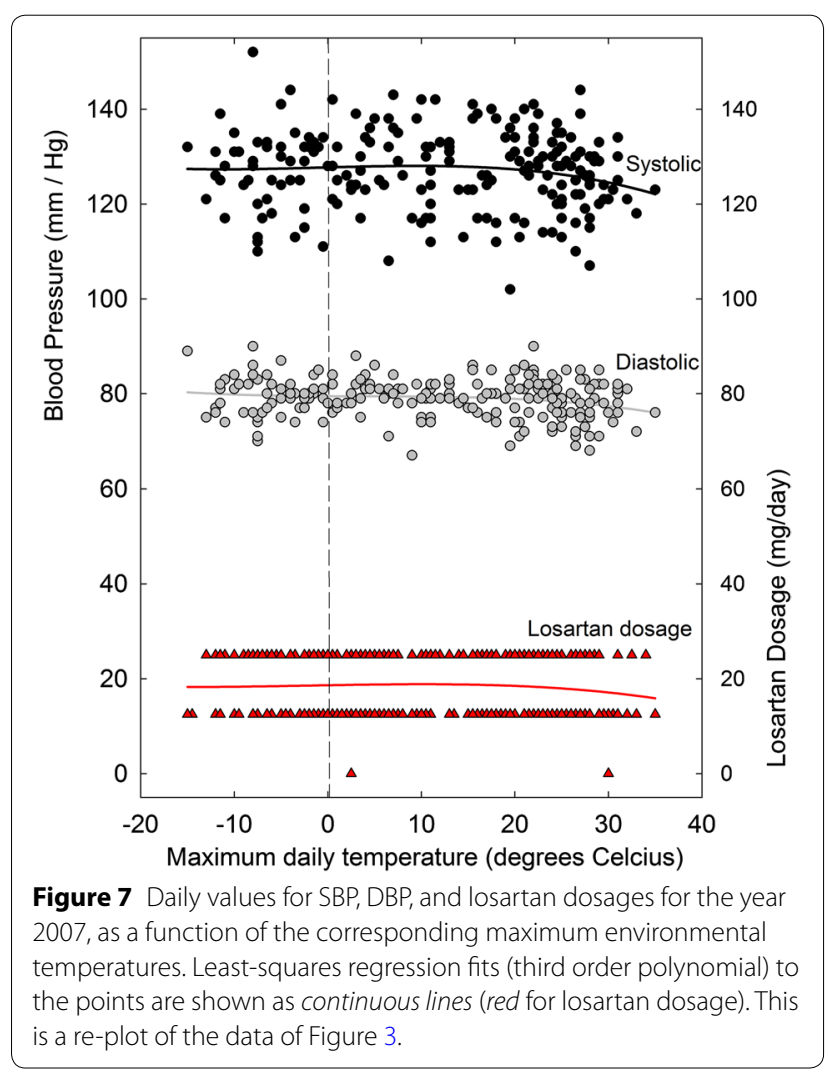

\section{Angiotensin II receptors}

Antihypertensive, dosage-dependent, effects of losartan were evident in early short-term studies with both 


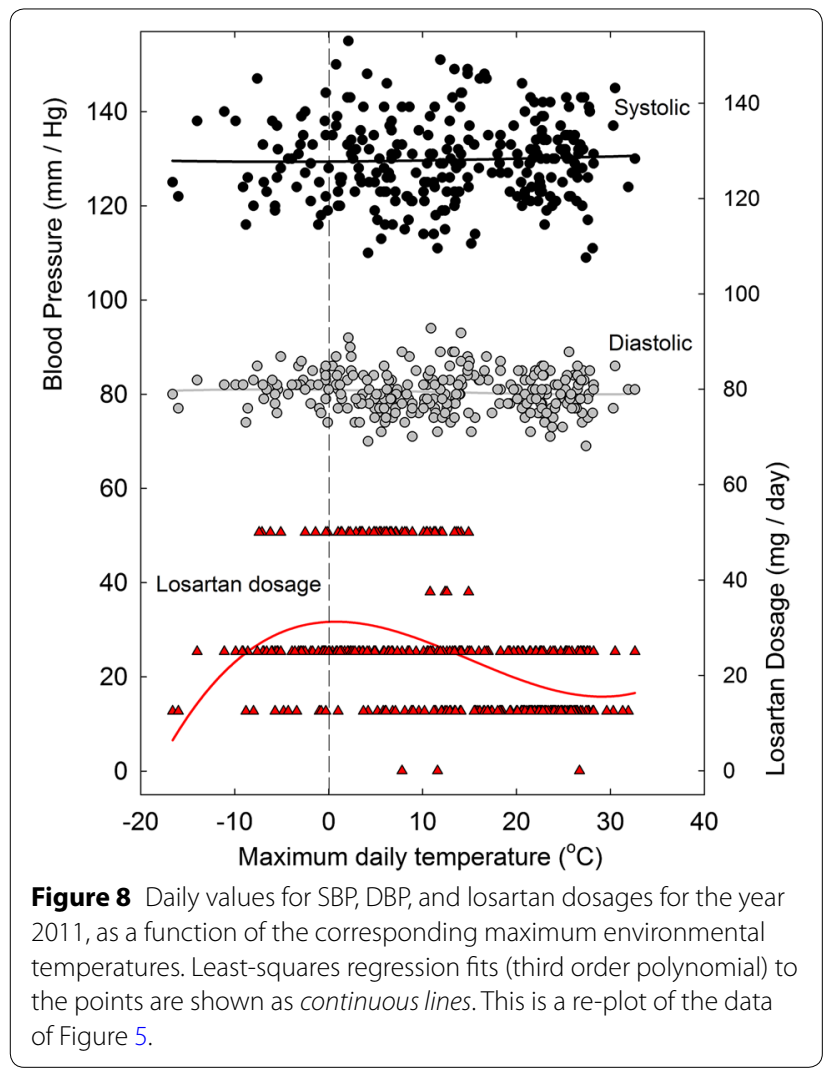

normal volunteers and patients [23]. Thus, Gottlieb et al. [24] noted in 1993 that vascular dilation and BP-lowering effects were maximal with $25 \mathrm{mg} /$ day and declined at higher doses, whereas effects deemed 'neurohormonal', such as increased levels of renin and of the circulating angiotensin II octapeptide (Ang II), continued to increase at higher concentrations. With the present subject, summer losartan hypersensitivity became most evident when dosage increased from around 25 to $50 \mathrm{mg} /$ day, consistent with a neurohormonal influence.

Cell surface Ang II receptors (subtypes $\mathrm{AT}_{1} \mathrm{R}$ and $\left.\mathrm{AT}_{2} \mathrm{R}\right)$ are present in various mammalian species. It is the reaction of Ang II with $\mathrm{AT}_{1} \mathrm{R}$, the dominant high-affinity receptor, that is blocked with high specificity by losartan [25]. Independently of losartan, the reaction normally triggers $G_{q}$-protein signalling that mobilises intracellular $\mathrm{Ca}^{++}$, resulting in increased vascular tone. Such signalling is itself susceptible to modulation by regulatory factors-such as Regulator of G-Protein Signaling-2 (RGS-2) [18-20]-which are themselves subject to regulatory inputs. So determining how seasonal factors feed into this system, and whether the key seasonal factor is, indeed, temperature $[11,26]$, are unlikely to be easy.

Although bound to plasma albumin, losartan itself is rapidly degraded to a longer-lived, pharmacologically more potent, carboxylic acid derivative, also bound to

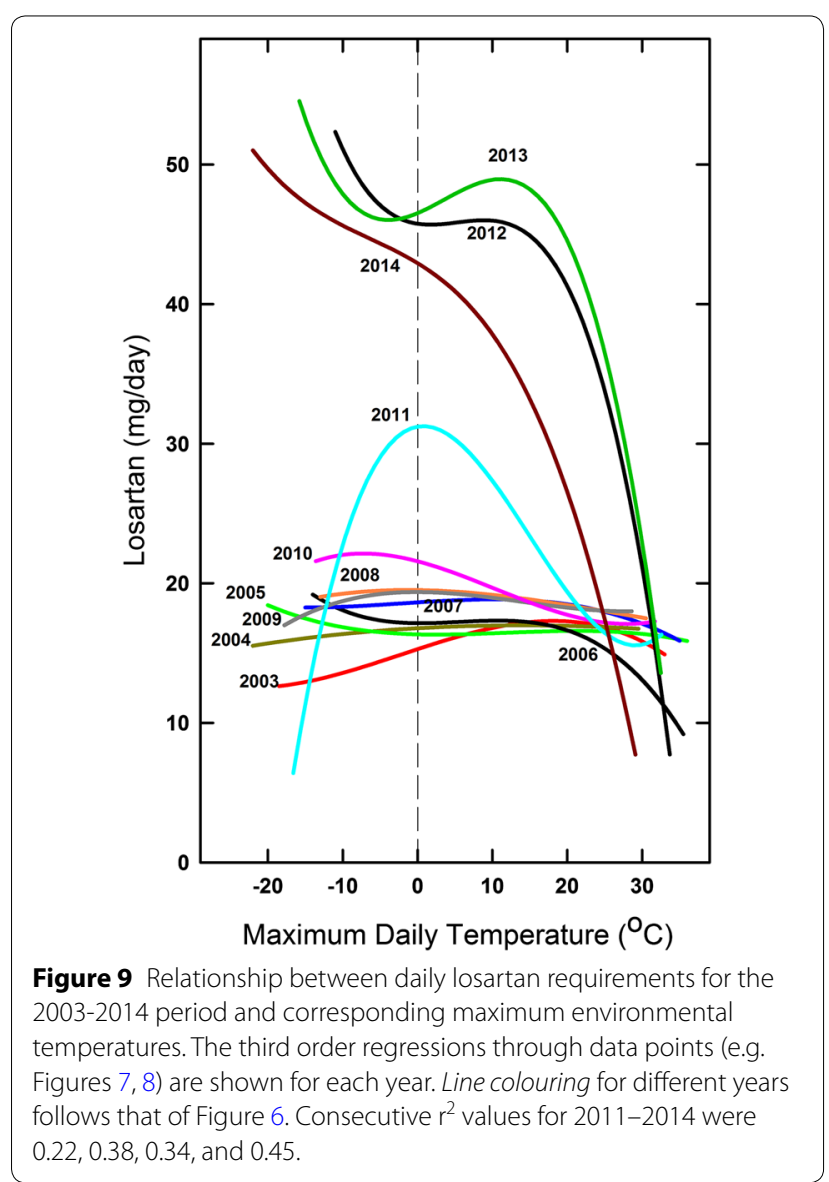

albumin; this sustains $\mathrm{AT}_{1} \mathrm{R}$ blockade non-competitively for many hours $[27,28]$. Thus, provided a sufficient dose is employed, and the period between doses is not too long, successive losartan doses may act cumulatively. This is consistent with the observation that, in the spring of 2000, following the implementation, and then cessation, of losartan therapy, BP values fell progressively, and rose progressively, each over several days (Figure 1). However, when losartan was restarted in the summer of 2002, the fall was immediate. This hinted at an additional seasonal influence, conditional on losartan dosage that would be uncovered ("unmasked") in later years (Figures 6, 9).

\section{Unmasking of angiotensin II subtype 2 receptors}

Treatment with ACE inhibitors lowers the circulating concentration of Ang II, so decreasing its reaction with the dominant $\mathrm{AT}_{1} \mathrm{R}$ subtype, and thus lowering $\mathrm{BP}$. However, the increase in the circulating concentration of Ang II, following blockage of the $\mathrm{AT}_{1} \mathrm{R}$ subtype with losartan, should suffice to affect the losartan-insensitive, low abundance, $\mathrm{AT}_{2} \mathrm{R}$ subtype. Activation of $\mathrm{AT}_{2} \mathrm{R}$ usually counteracts the effects of $\mathrm{AT}_{1} \mathrm{R}$ activation (e.g. vasodilation not vasoconstriction) $[29,30]$. It is reported for 
hypertension-prone rats that Ang II will cause $\mathrm{AT}_{2} \mathrm{R}$ mediated vasodilation, provided $\mathrm{AT}_{1} \mathrm{R}$ is blocked and $\mathrm{AT}_{2} \mathrm{R}$ expression is upregulated [31,32]. Thus, activation of $\mathrm{AT}_{2} \mathrm{R}$ is conditional, and is described as being "unmasked" or "trumped" when $\mathrm{AT}_{1} \mathrm{R}$-mediated effects are inhibited by agents such as losartan [33-35]. Indeed, Abdulla and Johns [36] recently reported for rats that losartan increased the fall in $\mathrm{BP}$ following the $\mathrm{AT}_{2} \mathrm{R}$ receptor-associated inhibition of renal sympathetic nerve activity, which was part of the homeostatic response to total body fluid volume expansion, such as normally occurs in humans in summertime [37]. They concluded that: "The basal level of central $\mathrm{AT}_{2}$ receptor activation is not involved in the normal renal sympatho-inhibition due to volume expansion, unless the counter-regulatory $\mathrm{AT}_{1}$ receptors are blocked". Thus, there is again an "unmasking" effect of losartan. These conclusions from rodents are supported by studies of Bartter and Gitelman syndromes (BS/GS) patients, where there is endogenous antagonism of $\mathrm{AT}_{1} \mathrm{R}$ signalling that in many respects resemble inhibition by losartan (e.g. Ang II elevation) [38, 39].

\section{Hypothesis}

A working hypothesis, consistent with animal experiments and BS/GS studies, is that under conditions of heat-stress (e.g. vascular dilation, salt loss), there is increased expression of a countervailing, losartaninsensitive, receptor subtype $\left(\mathrm{AT}_{2} \mathrm{R}\right)$. By lowering $\mathrm{BP}$ in response to antiotensin-II, $\mathrm{AT}_{2} \mathrm{R}$ would facilitate finetuning of the $\mathrm{AT}_{1} \mathrm{R}$-mediated vasoconstriction that supports $\mathrm{BP}$ when superficial veins dilate to enhance body cooling. This $\mathrm{AT}_{2} \mathrm{R}$ activity might be sufficient to explain a small summertime BP dip found in normal human subjects whose Ang II levels are not increased (Figure 2). The dip would be greatly enhanced when Ang II levels are increased at higher losartan dosages. Under this condition, the excess of Ang II would be expected to react with the $\mathrm{AT}_{2} \mathrm{R}$, so greatly amplifying the losartan-induced fall in BP. To this extent, the present human study is supportive of most rodent and BS/GS studies. The hypothesis predicts that summertime dips would be decreased either by $\mathrm{ACE}$ inhibitors, or by $\mathrm{AT}_{2} \mathrm{R}$ antagonists, such as EMA401 [40]. Indeed, the study of benazepril by Chen et al. [15] supports the hypothesis and is in keeping with the recommended caution regarding combination therapy with $\mathrm{ACE}$ inhibitors and $\mathrm{ARBs}[41] . \mathrm{AT}_{2} \mathrm{R}$ agonists, including truncated Ang II fragments, are possible novel antihypertensive agents [34].

\section{Night-time dipping}

ABP recordings often reveal a small dip in BP values when subjects are resting at night. Although carried out on biased groups (members of different summer and winter populations that had been selected to attend hypertension clinics), ABP studies in Italy $[2,3]$ found that, in summertime, night-time dipping was less evident and SBPs were slightly increased; it was only with daytime BP measurements that the summertime decrease was evident. The night-time SBP increase was particularly apparent in elderly subjects receiving antihypertensive medication (type not specified). While noting that "milder sleep problems associated with hot weather cannot be completely excluded" [3], and that there may be "different sleeping behaviors between summer and winter" [2], the authors suggested that there is often a, clinic-directed or self-directed, reduction in medication in summertime, either because of a measured daytime lowering of BP, or because it is "common knowledge" that such lowering would have occurred [2]. Thus, those who would reduce the number of medications, or reduce dosages (as in the present study), were cautioned by Modesti et al. [3] that "the results of our study clearly indicate that the practice of reducing treatment in the summer in the elderly based on low clinic BP values is not good, because it might be responsible for a potentially dangerous increase in night BP".

Nevertheless, given that hypertension-related adverse cardiovascular events are less in summer, then correcting, at this time of the year, for the daytime decrease in SBP, may be more important that correcting for a nighttime increase. Determining the swings and roundabouts of this is a matter for future study, but a prudent interim measure might be to take some or all of whatever medications are deemed necessary in hot weather, late in the evening. Such a season-tailored 'chronotherapeutic approach' $[12,42]$ touches on the issue of the period of bioavailability of a medication after ingestion (as discussed above $[27,28])$.

\section{Conclusions}

There should be greater awareness that the inflection points on J-curves [43] might vary on a seasonal basis. This awareness should encourage close self-monitoring of BP, with appropriate adjustment of medication dosage, especially in the case of losartan. Such dosage adjustment may be necessary for those living in, or travelling to, geographical regions where temperatures are seasonally or continually high. Assuming temperature to be primary, then this caveat might also apply to those engaging in hot activities (e.g. Turkish baths, hot yoga). More comprehensive softwares in BP monitoring devises might take into account both environmental temperatures and recent $\mathrm{BP}$ readings, and automatically recommend daily medication adjustment. Although randomized, double-blind, trials, may sometimes lead to proposals for 
increases in losartan dosages (e.g. Konstam et al. [44] advise elevation from 50 to $150 \mathrm{mg}$ ), it would seem that the climate of the country where such trials had taken place should be considered when assessing the risk-benefits of such regimens. Indeed, hypertension has been invoked as a factor explaining higher mortality in cold climates [45]. Sadly, studies of ARB-induced hypotension and AKI, both in the elderly [46], and in diabetic patients [47], give little weight to seasonal factors and dosage variation. An association of medication-induced hypotension with cognitive impairment in the elderly has led to disparagement of "one size fits all" approaches to therapy [48]. Finally, as noted by Verberk et al. [49] there may be direct economic benefits to health care systems if excessive dosages of costly medications are avoided.

\section{Endnotes}

${ }^{a}$ This paper is dedicated to W. Stanley Peart and James F. Mowbray, whose mentorship in times long past guided me to the road 'less travelled by'.

b The office of David J. Hemings.

\section{Author's contributions}

Donald Forsdyke is responsible for all aspects of this paper.

\section{Compliance with ethical guidelines}

\section{Competing interests}

The author declares that he has no competing interests.

Received: 8 April 2014 Accepted: 29 May 2015

Published online: 09 June 2015

\section{References}

1. Charach G, Rabinovich PD, Weintraub M (2004) Seasonal changes in blood pressure and frequency of related complications in elderly Israeli patients with essential hypertension. Gerontol 50:315-321

2. Fedecostante M, Barbatelli P, Guerra F, Espinosa E, Dessi-Fulgheri P, Sarzani $R$ (2012) Summer does not always mean lower: seasonality of $24 \mathrm{~h}$, daytime, and night-time blood pressure. J Hypertens 30:1392-1398

3. Modesti PA, Morabito M, Bertolozzi I, Massetti L, Panci G, Lumachi $C$ et al (2006) Weather-related changes in 24-h blood pressure profile: effects of age and implications for hypertension management. Hypertension 47:155-161

4. Lewington S, Li L, Sherliker P, Guo Y, Millwood I, Bian Z et al (2012) Seasonal variation in blood pressure and its relationship with outdoor temperature in 10 diverse regions of China: the China Kadoorie Biobank. J Hypertens 30:1383-1391

5. Modesti PA (2013) Season, temperature and blood pressure: a complex interaction. Eur J Int Med 24:604-607

6. Hozawa A, Kuriyama S, Shimazu T, Ohmori-Matsuda K, Tsuji I (2011) Seasonal variation in home blood pressure measurements and relation to outside temperature in Japan. Clin Exp Hypertens 33:153-158

7. Aubinière-Robb L, Jeemon P, Hastie CE, Patel RK, McCallum L, Morrison LD et al (2013) Blood pressure response to patterns of weather fluctuations and effect on mortality. Hypertension 62:190-196

8. Tu Y-K, Chien K-L, Chiu Y-W, Ellison GTH (2013) Seasonal variation in blood pressure is modulated by gender and age but not by BMI in a large Taiwanese population, 1996-2006. J Am Soc Hypertens 7:216-228
9. Floras JS (2013) Blood pressure variability: a novel and important risk factor. Can J Cardiol 29:557-563

10. Messerli FH, Williams B, Ritz E (2007) Essential hypertension. Lancet 370:591-603

11. Modesti PA, Morabito M, Massetti L, Rapi S, Orlandini S, Mancia G et al (2013) Seasonal blood pressure changes. An independent relationship with temperature and daylight hours. Hypertension 61:908-914

12. Cuspidi C, Ochoa JE, Parati G (2012) Seasonal variations in blood pressure: a complex phenomenon. J Hypertens 30:1315-1320

13. Tomlinson LA, Abel GA, Chaudhry AN, Tomson CR, Wilkinson IB, Roland MO et al (2013) ACE inhibitor and angiotensin-II receptor antagonist prescribing and hospital admissions with acute kidney injury: a longitudinal ecological study. PLoS One 8:e78465

14. Handler J (2011) Seasonal variability of blood pressure in California. J Clin Hypert 50:856-860

15. Chen Q, Wang J, Tian J, Tang X, Yu C, Marshall RJ et al (2013) Association between ambient temperature and blood pressure and blood pressure regulators: 1831 hypertensive patients followed up for 3 years. PLoS One 8(12):e84522

16. Mancia G, Grassi G (2014) Aggressive blood pressure lowering is dangerous: the J-curve: pro side of the argument. Hypertension 63:29-36

17. Forsdyke DR (2013) Seasonal dosage-dependent hypersensitivity to the angiotensin II receptor blocker, losartan: a case report and review. PeerJ PrePrints 1:e144v1

18. Siderovski DP, Heximer SP, Forsdyke DR (1994) A human gene encoding a putative basic helix-loop-helix phosphoprotein whose messenger-RNA increases rapidly in cycloheximide-treated blood mononuclear cells. DNA Cell Biol 13:125-147

19. Tang M, Wang G, Lu P, Karas RH, Aronovitz M, Heximer SP et al (2003) Regulator of G-protein signaling-2 mediates vascular smooth muscle relaxation and blood pressure. Nat Med 9:1506-1512

20. Calò LA, Pagnin E, Davis PA, Sartori M, Ceolotto G, Pessina AC et al (2004) Increased expression of regulator of $G$ protein signaling-2 (RGS-2) in Bartter's/Gitelman's syndrome. A role in the control of vascular tone and implication for hypertension. J Clin Endocrinol Metab 89:4153-4157

21. Tracey KJ (2014) Hypertension: an immune disorder? Immunity 41:673-674

22. Schutte R, Thijs L, Liu Y-P, Asayama K, Jin Y, Odili A et al (2012) Withinsubject blood pressure level, not variability, predicts fatal and nonfatal outcomes in a general population. Hypertension 60:1138-1147

23. Christen Y, Waeber B, Nussberger J, Porchet M, Borland RM, Lee RJ et al (1991) Oral administration of DuP 753, a specific angiotensin II receptor antagonist, to normal male volunteers. Inhibition of pressor response to exogenous angiotensin I and II. Circulation 83:1333-1342

24. Gottlieb SS, Dickstein K, Fleck E, Kostis J, Levine TB, LeJemtel T et al (1993) Hemodynamic and neurohormonal effects of the angiotensin II antagonist losartan in patients with congestive heart failure. Circulation 88:1602-1609

25. Wong PC, Barnes TB, Chiu AT, Christ DD, Duncia JV, Herblin WF et al (1991) Losartan (DuP 753), an orally active nonpeptide angiotensin II receptor antagonist. Cardiovasc Drug Rev 9:317-339

26. Schwartz BG, Kloner RA (2012) Seasonal variation in cardiac death rates is uniform across different climates. Circulation 126:A11723

27. Munafo A, Christen Y, Nussberger J, Shum LY, Borland RM, Lee RJ et al (1992) Drug concentration response relationships in normal volunteers after oral administration of losartan, an angiotensin II receptor antagonist. Clin Pharmacol Ther 51:513-521

28. Lo M-W, Goldberg MR, McCrea JB, Lu H, Furtek Cl, Bjornsson TD (1995) Pharmacokinetics of losartan, an angiotensin II receptor antagonist, and its active metabolite EXP3 174 in humans. Clin Pharmacol Ther 58:641-649

29. Matsubara H (1998) Pathophysiological role of angiotensin II type 2 receptor in cardiovascular and renal diseases. Circ Res 83:1 182-1191

30. de Gasparo M, Catt KJ, Inagami T, Wright JW, Unger T (2000) International Union of Pharmacology. XXIII. The Angiotensin II Receptors. Pharm Rev 52:415-472

31. Cosentino F, Savoia C, De Paolis P, Francia P, Russo A, Maffei A et al (2005) Angiotensin II type 2 receptors contribute to vascular responses in spontaneously hypertensive rats treated with angiotensin II type 1 receptor antagonists. Am J Hypertens 18:493-499 
32. Savoia C, Tabet F, Yao G, Schiffrin EL, Touyz RM (2005) Negative regulation of Rho/Rho kinase by angiotensin II type 2 receptor in vascular smooth muscle cells: role in angiotensin II-induced vasodilation. J Hypertens 23:1037-1045

33. Li XC, Widdop RE (2004) AT2 receptor-mediated vasodilatation is unmasked by AT1 receptor blockade in conscious SHR. Brit J Pharm 142:821-830

34. McCarthy CA, Widdop RE, Denton KM, Jones ES (2013) Update on the angiotensin $\mathrm{AT}_{2}$ receptor. Curr Hypertens Rep 15:25-30

35. Schalekamp MADH, Danser AHJ (2013) How does the angiotensin II type 1 receptor 'trump'the type 2 receptor in blood pressure control? J Hypertens 31:705-712

36. Abdulla MH, Johns EJ (2013) Role of angiotensin AT2 receptors and nitric oxide in the cardiopulmonary baroreflex control of renal sympathetic nerve activity in rats. J Hypertens 31:1837-1846

37. Kristal-Boneh E, Froom P, Harari G, Shapiro Y, Green MS (1993) Seasonal changes in red blood cell parameters. Br J Haematol 85:603-607

38. Calò L, Davis PA, Rossi GP (2014) Understanding the mechanisms of angiotensin II signaling involved in hypertension and its long-term sequelae: insights from Bartter's and Gitelman's syndromes, human models of endogenous angiotensin II signaling antagonism. J Hypert 32:2109-2119

39. Maiolino G, Naso E, Calò LA (2014) Angiotensin II type 2 receptor effects: lesson from a human model of vascular hyporeactivity. Letter regarding Kemp et al. Circ Res 115:e24-e25

40. Rice ASC, Dworkin RH, McCarthy TD, Anand P, Bountra C, McCloud PI et al (2014) EMA401, an orally administered highly selective angiotensin II type 2 receptor antagonist, as a novel treatment for postherpetic neuralgia: a randomised, double-blind, placebo-controlled phase 2 clinical trial. Lancet 383:1637-1647

41. James PA, Oparil S, Carter BL, Cushman WC, Dennison-Himmelfarb C, Handler J et al (2014) 2014 evidence-based guideline for the management of high blood pressure in adults: report from the panel members appointed to the Eighth Joint National Committee (JNC 8). JAMA 311:507-520
42. Paratia G, Bilo G (2010) Evening administration of antihypertensive drugs: filling a knowledge gap. J Hypertens 28:1390-1392

43. Fuchs FD, Fuchs SC (2014) Blood pressure targets in the treatment of high blood pressure: a reappraisal of the J-shaped phenomenon. J Hum Hypertens 28:80-84

44. Konstam MA, Neaton JD, Dickstein K, Drexler H, Komajda M, Martinez FA et al (2009) Effects of high-dose versus low-dose losartan on clinical outcomes in patients with heart failure (HEAAL study): a randomised, double-blind trial. Lancet 374:1840-1848

45. Gasparrini A, Guo Y, Hashizume M, Lavigne E, Zanobetti A, Schwartz J et al (2015) Mortality risk attributable to high and low ambient temperature: a multicountry observational study. Lancet. doi:10.1016/ S0140-6736(14)62114-0

46. Elgendy IY, Huo T, Chik V, Pepine CJ, Bavry AA (2015) Efficacy and safety of angiotensin receptor blockers in older patients: a meta-analysis of randomized trials. Am J Hypert 28:576-585

47. Palmer SC, Mavridis D, Navarese E, Craig JC, Tonelli M, Salanti G et al (2015) Comparative efficiency and safety of blood pressure-lowering agents in adults with diabetes and kidney disease: a network meta-analysis. Lancet 385:2047-2056

48. Sanayan B, Westendorp RGJ (2015) Blood pressure control and cognitive impairment-why low is not always better. JAMA Int Med 175:586-587

49. Verberk WJ, Kroon AA, Lenders JWM, Kessels AGH, van Montfrans GA, Smit AJ et al (2007) Self-measurement of blood pressure at home reduces the need for antihypertensive drugs. A randomized, controlled trial. Hypertension 50:1019-1025

\section{Submit your next manuscript to BioMed Central and take full advantage of:}

- Convenient online submission

- Thorough peer review

- No space constraints or color figure charges

- Immediate publication on acceptance

- Inclusion in PubMed, CAS, Scopus and Google Scholar

- Research which is freely available for redistribution

Submit your manuscript at

www.biomedcentral.com/submit

C) Biomed Central 